\title{
Best Practices of Leading Public Pension Funds: Is the GSIS up to it?
}

Balaba JML

Department of Accountancy and Economics, University of the City of Manila, Manila, Philippines

\begin{abstract}
The research looks into the structure, conduct and performance of the world's leading pension funds, namely the ABP (The Netherlands) and California Public Employees' Retirement System (U.S.A.), and benchmarks the Government Service Insurance System (Philippines) against the best practices instituted by these leading organizations. A Survey of Awareness and Practices of the GSIS Pension Fund is included in the research to validate the GSIS fund performance.
\end{abstract}

Keywords: Pension funds; ABP; CalPERS ; GSIS; Social security; Best practices; ESG guidelines; Corporate governance; Code of ethics; Global Sullivan principles

\section{Introduction}

What is a pension system? What are its goals?

These two questions are at the heart of this study. But more than defining a pension system and its goals, this study delves deeper into the questions critical to a pension fund system. These concern its stability in providing for services as well as its potential for growth in providing for benefits. Thus, the central argument proposed, developed and analyzed in this study is this: best practices ensure growth of the pension fund and adequacy of its services.

For this purpose, this study looks into mandatory pension schemes, established by law and compelling at least some category of the economically active population to participate. In this instance, mandatory retirement and pension coverage for civil servants or workers in the government is the subject of this research.

The goal of a pension system is to provide for replacement for labor earnings lost as a result of old age, premature death, invalidity, and temporary or permanent work injury. Public pension systems seek to address the duty to ensure a minimum income or replace a predictable percentage of lost earnings [1]. Many public pension funds are largely defined benefit schemes financed on a pay-as-you-go basis [2].

In Asia, the three main types of public pension systems in the region are: provident funds, defined benefit systems in market economies, and pension schemes in transition economies. While the magnitude and nature of problems differ from country to country, most pension schemes have common problems such as affordability, poor returns on financial assets, inadequate service levels, and inefficient administration [3].

In many countries, public pension funds are among the largest in terms of assets and number of participants and constitute an important share of financial assets. In 2005, the 10 worldwide largest pension funds worldwide in terms of assets were occupational schemes for civil servants, (www.watsonwyatt.com ).

Approximately 800 million people, or one-third of the world's labor force, are covered by publicly-managed pension fund schemes (www.financelearning.org/ppfm2004).

The management of these publicly-managed pension funds has been subject of much debate and attention owing to its sheer size and potential impact on financial stability as well as its sustainability to provide for future benefits.
Consider, the stock of pension assets of these public pension funds alone amount to fifty percent of the world's gross domestic product.

Focusing on these public pension funds and the GSIS pension fund, the paper will look into the best practices adopted to safeguard the growth and sustainability of the public pension funds.

\section{Review of Related Literature}

\section{Defining a pension fund}

Pension funds are a form of social protection scheme that protects the population from economic hardship associated with social risks such as old age, sickness, accident, death of the breadwinner and/or unemployment [4]. Pension funds are established to provide safety nets to its members in their old age. The term "social security" is often used to refer also to pension fund systems [5]. However, social security should be seen strictly as both a process and result of means to ensure poverty relief or prevent it and maintain incomes by replacing incomes lost as a result of prescribed contingencies ISSA [6]. Social security comprises the length of health care and health insurance, life insurance, retirement, disability, maternity and unemployment insurance. Pension funds particularly and specifically consider safety nets for old age needs and entail the consideration of retirement and pension schemes for members of the fund.

The International Labor Organization (ILO) established the minimum standards for the financing, benefit structure and administration of social security schemes, the most important of which are consolidated in Convention No. 102 adopted in 1952 [7].

As so defined by Social Security Minimum Standards Convention No. 102, national security systems are enjoined to provide nine benefits, as follows:

1. Medical care;

2. Sickness benefit;

3. Maternity benefit;

*Corresponding author: Balaba JML, Adjunct lecturer, Department of Accountancy and Economics, University of the City of Manila, Manila, Philippines, Tel: +632527 7941; E-mail: jeaneth@rocketmail.com

Received May 13, 2015; Accepted May 21, 2015; Published May 28, 2015

Citation: Balaba JML (2015) TBest Practices of Leading Public Pension Funds: Is the GSIS up to it?. Bus Eco J 6: 159. doi:10.4172/2151-6219.1000159

Copyright: (c) 2015 Balaba JML. Attribution License, which permits unrestricted use, distribution, and reproduction in any medium, provided the original author and source are credited. 
4. Employment injury benefit;

5. Old age benefit;

6. Invalidity benefit;

7. Survivors' benefit;

8. Unemployment benefit;

9. Family benefit

By extension, a public pension fund, primarily a civil servants' pension fund, refers to pension fund schemes that cater to workers in government. Even so, public pension funds may also refer to mandatory publicly-managed pension systems for private workers. For our purpose, we use the term "public pension fund" to refer to the civil servants' pension fund. Strictly, a pension fund pertains to the administration of retirement and old age benefits for its members. A social security agency may also administer a pension fund.

\section{Characteristics of best practices}

Developing a best practices framework for any public pension fund requires that the fund's objectives are clear, free from conflict of interest, its operations transparent and its managers accountable to the fund's members for their decisions [5].

\section{Good governance}

Good governance is about establishing structures to ensure that a business is well run. Within the context of business enterprises, good corporate governance refers to the rules and practices that govern the relationship between the managers' and shareholders of corporations, as well as stakeholders like employees, pensioners and local communities [8]. Good corporate governance enhances accountability, transparency and fairness.

Within the context of allocating investment capital, institutional investors such as pension funds especially consider the governance profile of a market in making investment decisions, defined by the manner in which a market deals with issues like disclosure, insider trading and other investor protection issues ICGN [9].

Leading pension's funds have been shown to be committed to global corporate governance principles and have thrown support to the International Corporate Governance Network (ICGN) Statement on Global Corporate Governance Principles, among other internationallyrecognized corporate governance institutions.

\section{Accountability}

Accountability is about ensuring that the governance structures are effective by creating compatible incentives. It means establishing the criteria to measure the performance of officers as well as oversight mechanisms to ensure that standards are met. It renders officers answerable for their official behavior and responsive to the entity from which they derive their authority ADB [10].

\section{Transparency}

Transparency is about disclosing full information on the financial situation of the fund, investment decisions, composition of portfolio and performance. It means making available information to the general public and clarifying rules, regulations and decisions ADB [11].

\section{Social responsibility}

Corporate social responsibility is the commitment of business to contribute to sustainable economic development by behaving ethically and working with employees, their families, the local community and society at large to improve their quality of life WBCSD [12]. CSR is about how companies manage the business processes to produce an overall impact on society (www.mallenbaker.net).

\section{Responsible investment (ESG issues)}

Because of their primordial role as engines of economic growth as a source of funds for investment activities wherever, leading pension funds are increasingly constrained to incorporate environmental, social and corporate governance issues in their investment analysis and decision-making processes. The judicious application of ESG concerns have more often than not produced tangible profits and enhanced shareholder value.

Such concern for ESG issues requires that pension funds take an active role as investors in the companies they invest in, including governance practices and policies. Pension funds enter into collaborative engagements with institutions to promote responsible investment, engage companies on ESG issues and exercise voting rights or monitor compliance with voting policy [13].

Leading pensions funds have been signatory to the United Nations Principles of Responsible Investment launched in April 2006 and developed by an international group of investors to make ESG issues relevant to investment practice.

\section{The leading public pension funds and the GSIS}

The survey of leading public pension funds in this study selects several systems from the recent survey ranking (in terms of assets under management) conducted by the Watson Wyatt Company in 2006. The ranking based on 2005 figures is dominated by pension funds established for workers in government (national or local).

Two of these leading public pension funds, namely, ABP (Netherlands) and CalPERS (U.S.) are the focus of the benchmarking exercise. These two public pension funds have been selected owing to their consistent well-placed rank in the league of the world's leading pension funds. CalPERS also the model and benchmark for the investment strategy that the GSIS is adopting with respect to investing in the foreign markets. The best practices of several leading public pension funds in the world are documented in the exhaustive research by The United Nations Environment Programme Finance Initiative and The United Kingdom Social Investment Forum (2007) [14-17].

\section{Results and Discussion}

A closer look at the below areas of best practices and how these differ or are manifested in the benchmark pension funds is in order. Specifically, the following corporate governance parameters are considered along with the current practice adopted in the GSIS:

\section{Organization mandate}

$\mathrm{ABP}$ and CalPERS are differently organized. $\mathrm{ABP}$ is a non-profit institution organized under private law but governed by public rules and regulation.

ABP is cited as the best example of how civil servants' pension funds should be organized and rendered free from political pressure and improper interference from government in pursuing its objectives.

On the other hand, CalPERS is an independent pension fund created by state legislation. However, certain provisions in the State 
constitution protect the fund from political pressure. With respect to its responsible investment focus, research showed that the State of California prohibited CalPERS to invest in companies doing in Sudan that fail to take substantial action on human rights violations and required CalPERS to report any investment in Sudan [18-21].

The GSIS as a government financial institution whose Board of Trustees is appointed by the President of the Republic of the Philippines is not insulated from political pressure and its adverse effects.

\section{Investment strategy}

Both ABP and CalPERS are signatories to the UNPRI and have articulated as official policy their pursuit of responsible investment along the lines of adherence to good corporate governance practices from within their respective organizations and from the companies they invest in. Responsible investment strategies also consider very seriously the ramifications of ESG issues in their investment decisions.

GSIS is not signatory to the UNPRI or the ICGN or the Global Sullivan Principles. However, its entry into foreign investment markets will probably mean that it will consider these collaborative initiatives as a responsible pension fund investor [22].

\section{Accountability and oversight}

Corporate governance within the ABP and CalPERS are exercised by the respective boards. ABP has four boards while CalPERS has a single board responsible for all of CalPERS' pension plans. Both pension funds invoke transparency and accountability in ensuring that its members and stakeholders are furnished information and there is full disclosure of information in the investment interests of their funds. Updated information is easily available at their respective websites.

GSIS is governed by a Board of Trustees which is the policymaking body composed of the President and General Manager of the GSIS and eight representatives from the Philippine Public School Teachers Association of the Philippines or the Philippine Association of School Superintendents, leading government employee/retiree associations, banking/finance/investment/ insurance sector, and the legal profession. The PGM is the Vice-Chair of the Board and heads the GSIS management team as its CEO [23].

\section{Shareholder participation}

$\mathrm{ABP}$ is a long-term investor with an active corporate governance policy requiring from the companies it invests in high standards of transparency, independent supervision, accountability and respect for shareholder rights. ABP exercises these shareholder rights if it can contribute to the risk-return profile of its portfolio. ABP votes all its Dutch holdings directly or via proxy voting through Eumedion, its third-party representative. ABP votes in its international holdings in companies where it has at least investment of $\$ 13$ million, or about 1,000 companies in Europe, U.S.A, Canada and Australia [24].

Calper is a leading advocate and practitioner of active involvement in pension fund investments by primarily involving itself with corporate governance practices of the companies it invests in. CalPERS maintains a Focus List Program identifying poor-performing companies in which it has equity interests and proposes governance mechanisms that seek to improve company performance and enhance the shareholder value in the process.

GSIS is represented in the companies where it is entitled to a Board seat and votes in all issues brought before the Board meetings in these companies [25].

\section{Disclosure of information and transparency}

Both ABP and CalPERS are champions of good corporate governance and observe full disclosure of information in all critical aspects of governance and management, primarily using their respective website as tools for information dissemination.

\section{Inter-government relationship}

$\mathrm{ABP}$ maintains an exclusion policy for investments that contravene international law, avoiding investments directly related to violations of human rights and fundamental freedoms.

CalPERS has a policy on emerging markets equity investment which considers political stability of a country including civil liberties and independent legal system, transparency including press freedom and accounting standards, among others. In 2006, CalPERS adopted a strong position on Sudan for human rights violations unwittingly supported by companies and which pose risk to the long-term value of its investments [26].

\section{Code requirements for external fund managers}

Both ABP and CalPERS have strict requirements from its external fund managers to comply with Code requirements such as Ethics, Corporate Governance, Prudent Investments, Conflict of Interest and Proxy Voting Guidelines.

GSIS does not require the presentation of a Code of Ethics from its external fund managers but meticulously considers the reputation of the external fund managers as well as the credentials of the officers assigned to handle the GSIS fund [27].

\section{Organizational competency}

ABP's investment team utilizes the combined skills and management efforts of its legal, equity investment, and CSR and research departments. CalPERS has 215 people in its Investment Office implementing its various investment programs such as the Corporate Governance Focus List Program, Corporate Governance Investment Program, Environmental Corporate Governance Plan, GSIS has an Investment Office headed by a Vice-President and staffed with a Department Manager and 4 Accounts Managers and 18 staff officers, including 10 trading and senior trading specialists [28].

\section{Collaborative initiatives}

Both $\mathrm{ABP}$ and CalPERS enter into collaborative initiatives with other international pension funds and institutional investors in line with their responsible investment strategy. Among these initiatives are the International Corporate Governance Network, Global Investor Governance Network, Carbon Disclosure Project, and UN Principles for Responsible Investment.

GSIS is an active member of the Philippine Social Security Association (PhilSSA) and is affiliated with the International Social Security Association (ISSA), under the auspices of the International Labor Organization (ILO), and the ASEAN Social Security Association (ASSA) [29].

\section{Conclusion}

A full appreciation of the success of the adoption of best practices in two of the world's leading pension funds will probably require a more extensive research into the operational and financial impacts of such practices on the delivery of their "promise" of defined pension 
benefits and optimal yields for the members and participants of the pension fund.

From the vantage point of practical research, this business case for the adoption of best practices by the GSIS in the management of the pension fund particularly rests on two considerations:

1. There is imperative to look into the best practices of the world's leading pension funds in order to map out a defining investment strategy that will direct the management and growth of the funds of the GSIS.

2. There is impetus for the consideration of the concern and support of GSIS members for reforms (including adoption of best practices and ensuring its successful delivery) that will augur for their benefit in ensuring that the pension fund is responsive to their needs and their plight.

The argument that best practices contribute to the pension fund's adequacy and growth may not be demonstrated in clear financial and quantitative terms here. But it should suffice that our benchmarks, $\mathrm{ABP}$ and CalPERS, have consistently been well-placed among the world's pension funds in protecting its investible assets and the interest of its members at the least by pursuing a carefully crafted strategy of responsible investment complete with clear policy guidelines with which to realize the lofty goals of such a strategy. Thus, it bears to consider the best practices they have adopted and to appreciate perhaps the practical benefits of having the same for the GSIS.

\section{References}

1. Burtless G (1998) The Effect of Pension Privatization on National Saving and Capital Market Development. Proceedings of the APEC Regional Forum on Pension Reform. Manila: Asian Development Bank.

2. Carvalho-Pinheiro V (2004) Pension Funds for Government Workers in OECD Countries. OECD, Paris.

3. Auwera MV (2006) Pension Reform and ADB Interventions. Asian Development Bank, Manikla.

4. Huber E, Stephens JD (2001) The Political Economy of Pension Reform: Latin America in Comparative Perspective. Geneva 2000: The Next Step in Social Development.

5. Carmichael J, Palacios R (2003) A Framework for Public Pension Fund Management. $2^{\text {nd }}$ Public Pension Fund Management Conference. World Bank, Washington DC, USA.

6. International Social Security Association (2007) Social Security: Global Challenges and Regional Responses. International Social Security Association, Manila.

7. Charlton R, McKinnon R (2001) Pensions in Development. Business \& Economics, Ashgate Publishing, England.

8. Whitherell B (2002) OECD Principles of Corporate Governance and Responsibility: Foundations of Market Integrity. OECD Observer No. 234 OECD, Paris.

9. International Corporate Governance Network (2005) ICGN Statement on Global Corporate Governance Principles. Annual Conference in London.

10. Asian Development Bank (1999) Governance: Sound Development Management. ADB, Manila.

11. Asian Development Bank (1998) Promoting Pension Reform: A Critica Assessment of the Policy Agenda. ADB, Manila.

12. World Business Council for Sustainable Development (2000) Corporate Socia Responsibility: Making Good Business Sense.

13. Barr N (2001) The Truth about pension reform. Finance and Development International Monetary Fund.
14. Bateman H (1998) A Framework for Pension Reform in the APEC Economies Voluntary Principles and Collaborative Initiatives. Proceedings of the APEC Regional Forum on Pension Reform. Asian Development Bank, Manila.

15. Battle K, Edward T (2002) Public Pensions in a Development Context: The Case of Canada. UNRISD Programme on Social Policy and Development, Paper Number 31.

16. Carvalho-Pinheiro V (2004) Funded Pension Schemes for Government Workers: Proposal for Study. $3^{\text {rd }}$ OECD/INPRS Conference on Private Pensions in Asia. Manila, Philippines.

17. Demarco G, Rofman R (1998) Supervising Mandatory Pension Funds: Issues and Challenges. Washington DC, USA.

18. GFK (2005) Results of the Public Survey of Attitudes as for Pension Reform

19. Government Service Insurance System. Board of Trustees. Corporate Governance Committee Charter.

20. Holzmann R, MacArthur IW, Sin Y (2000) Pension Systems in East Asia and the Pacific: Challenges and Opportunities. The World Bank, Washington, DC, USA.

1. Neyra JQ (2007) Practicing Good Corporate Governance in GSIS: A Case Study on the Pensioner Monitoring System. MPA Thesis, University of Makati.

22. (2006) OECD Guidelines on Pension Fund Asset Management Recommendation of the Council. OECD, Paris.

23. Ortiz MD (2005) Developments in Public Old-Age Benefit Schemes in the Asia and Pacific Region. International Social Security Association, Seoul.

24. Republic of the Philippines (1996) Republic Act No. 8291: GSIS Act of 1997

25. Reynaud E (2000) Social Dialogue and Pension Reform. Geneva: International Labor Organization.

26. Shokeen P, Chotruangprasert K, Li D (2006) Assessing the Potential of Socially Responsible Investments in Asian Pension Systems.

27. The United Nations (2006) The Principles for Responsible Investment.

28. The United Nations Environment Programme Finance Initiative (Asse Management Group and The United Kingdom Social Investment Forum (Sustainable Pensions Project). (2007). Responsible Investment In Focus: How Leading Public Pension Funds Are Meeting The Challenge.

29. Turner J (2002) Social Security Development and Reform in Asia and the Pacific. The Pensions Institute, London. 